\title{
Bibliografía sobre organismos, ambientes y procesos marinos y atmosféricos en Bahía Culebra, Pacífico norte, Guanacaste, Costa Rica (1922-2012)
}

\author{
Jorge Cortés 1,2 \\ 1. Centro de Investigación en Ciencias del Mar Y Limnología (CIMAR), Ciudad de la Investigación, Universidad de \\ Costa Rica, San Pedro, 11501-2060 San José, Costa Rica. jorge.cortes@ucr.ac.cr \\ 2. Escuela de Biología, Universidad de Costa Rica, San Pedro, 11501-2060 San José, Costa Rica.
}

\author{
Recibido 27-IX-2011. Corregido 03-II-2012. Aceptado 15-II-2012.
}

\begin{abstract}
Bibliography on marine organisms, environments, and oceanographic and atmospheric processes in Bahía Culebra, north Pacific, Costa Rica (1922-2012). Bahía Culebra is located on the north Pacific coast of Costa Rica. It is a seasonal upwelling area, rich in marine ecosystems and organisms, and the main tourist development area in the country. Here, I compiled and analyzed a list of 182 publications in scientific journals, and 23 thesis, reports and books in which marine organisms, environments and marine and atmospheric processes from Bahía Culebra or in which the Bay are mentioned is presented and analyzed. The majority of the publications, starting with a paper from 1922 on a polychaete worm, are on biodiversity and ecology. The are no publications on some environments, for example the benthonic fauna of soft bottoms, or on some taxa, for example, flat worms. More work is needed on fisheries and management of the organisms and environments of Bahía Culebra. Rev. Biol. Trop. 60 (Suppl. 2): 231-242. Epub 2012 April 01.
\end{abstract}

Key words: Biodiversity, marine ecology, geology, oceanography, pollution, atmospheric sciences, bibliography, Culebra Bay, Eastern Pacific, Costa Rica.

Bahía Culebra, en el Pacífico norte de Costa Rica, es una región con una larga historia geológica (Herrera-Zúñiga \& Vargas 2012) y de ocupación humana (Sánchez-Noguera 2012), y es también rica en biodiversidad (Cortés et al. 2012). En este trabajo he recopilado todas las publicaciones sobre temas atmosféricos, oceanográficos y biológicos sobre los ambientes marinos de Bahía Culebra. Se analizan las publicaciones y se apuntan vacíos del conocimiento.

\section{MATERIALES Y MÉTODOS}

Se hizo una búsqueda lo más exhaustiva posible, incluyendo consultas a expertos, sobre los trabajos publicados sobre Bahía Culebra. Cada publicación fue clasificada según su tema para visualizar los vacíos de información existentes.

\section{RESULTADOS Y DISCUSIÓN}

Se encontraron 182 publicaciones en revistas científicas (Cuadro 1) y 23 tesis, informes y libros (Cuadro 2) sobre organismos, ambientes y procesos marinos y atmosféricos en Bahía Culebra o donde se menciona la Bahía. De esos, la mayoría, 54\%, son sobre biodiversidad, principalmente sobre crustáceos, moluscos y cnidarios (Cuadro 3), seguido por publicaciones sobre ecología, $21 \%$. En cuanto a ambientes, los arrecifes y comunidades coralinas, son de los que más se ha escrito, seguido por manglares (Cuadro 3). No hay una sola publicación sobre el bentos suave de la Bahía o sobre algunos grupos de organismos que viven allí, por ejemplo, gusanos planos de vida libre o sobre nemátodos (Cortés et al. 2012); no hay trabajos sobre genética o evolución. Como tampoco publicaciones específicas sobre pesquería en Bahía Culebra. 
Bahía Culebra es rica en biodiversidad con procesos de gran interés, y con una gran presión por la actividad turística, sin embargo, solamente una publicación toca el tema de manejo de los ambientes marinos. Aunque Bahía Culebra ha sido estudiada desde hace mucho tiempo, faltan investigaciones sobre algunos temas, grupos de organismos y muy importante sobre pesquería y manejo e impacto sobre los organismos y ambientes marinos de la Bahía.

\section{AGRADECIMIENTO}

Kay Hale, exDirectora de la Biblioteca de RSMAS, Universidad de Miami y ahora en Mote Marine Laboratory, me ha suministrado, desde hace varias décadas y hasta el presente, publicaciones de muy difícil acceso; igualmente Harlan K. Dean me ha conseguido trabajos muy antiguos. Susan M. Stover, Directora Mote Library me ha ayuda en años recientes a obtener publicaciones díficles de conseguir.
Le agradezco a Juan José Alvarado, Percy Denyer y Eric Alfaro el envío de varias referencias y artículos.

\section{RESUMEN}

Bahía Culebra se locoaliza en la parte norte de la costa Pacífica de Costa Rica. Es una región de afloramiento estacional, rica en ambientes y organismos marinos, y además, la zona de mayor desarrollo turístico del país. En este trabajo compilo y analizo una lista de 182 publicaciones en revista científcas y 23 tesis, informes y libros sobre organismos, ambientes y procesos marinos y atmosféricos en Bahía Culebra o donde se menciona la Bahía, se presentan y analizan. La gran mayoría de los trabajos, empezando en 1922 con la descripción de un poliqueto, son sobre biodiversidad y ecología. Faltan trabajos sobre algunos ambientes de la bahía, por ejemplo, el bentos de los fondos blandos, y grupos de organismos, por ejemplo, sobre gusanos planos de vida libre. Faltan investigaciones sobre pesquería y manejo de los organismos y ambientes marinos de la Bahía.

Palabras clave: Biodiversidad, ecología marina, geología, oceanografía, ciencias atmosféricas, bibliografía, Bahía Culebra, Pacífico Oriental, Costa Rica

CUADRO 1

Lista de publicaciones en revista científicas sobre organismos, ambientes y procesos marinos y atmosféricos de Bahía Culebra o donde se menciona la Bahía. En paréntesis los códigos de clasificación, ver Cuadro 3

TABLE 1

List of publications in scientific journals in which marine organisms, environments and marine and atmospheric processes from Bahía Culebra or in which the Bay are mentioned. In parenthesis the classification codes, see Table 3

Acuña, J., J. Cortés \& M. Murillo. 1996/1997. Mapa de sensibilidad ambiental para derrames de petróleo en las costas de Costa Rica. Rev. Biol. Trop. 44(3)/45(1): 463-470. (Q, Cp)

Acuña-González, J.A., J.A. Vargas-Zamora, E. GómezRamírez \& J. García-Céspedes. 2004. Hidrocarburos de petróleo, disueltos y dispersos, en cuatro ambientes costeros de Costa Rica. Rev. Biol. Trop. 52 (Supl. 2): 43-50. (Q, Cp)

Ajtai, P., Y. Camacho-García \& I.S. Wehrtmann. 2003. Range extension of Crosslandia daedali (Nudibranchia: Scyllaeidae). Rev. Biol. Trop. 51: 274. (B, Mg)
Alfaro, E.J. \& J. Cortés. 2012. Atmospheric forcing of cool subsurface water events in Bahía Culebra, Costa Rica. Rev. Biol. Trop. 60 (Supl. 2): 173-186. (Af, Ct, Of)

Alfaro, E.J., J. Cortés, J.J. Alvarado, C. Jiménez, A. León, C. Sánchez-Noguera, J. Nivia-Ruiz \& E. RuizCampos. 2012. Clima y variabilidad climática de la temperatura subsuperfical del mar en Bahía Culebra, Guanacaste, Costa Rica. Rev. Biol. Trop. 60 (Supl. 2): 159-171. (Af, Ct, Of)

Alvarado. J.J. 2008. Seasonal occurrence and aggregation behavior of the sea urchin Astropyga pulvinata (Echinodermata: Echinoidea) in Bahía Culebra, Costa Rica. Pac. Sci. 62: 579-592. (E, Ee) 
Alvarado, J.J. \& R. Vargas-Castillo. 2012. Invertebrados asociados al coral Pocillopora damicornis (Linnaeus, 1758) en Playa Blanca, Bahía Culebra, Costa Rica. Rev. Biol. Trop. 60 (Supl. 2): 77-92. (B, Cd, CnA, E)

Alvarado, J.J., J. Cortés \& H. Reyes-Bonilla. 2012. Bioerosion impact model of the sea urchin Diadema mexicanum on three Costa Rican Pacific coral reefs. Rev. Biol. Trop. 60 (Suppl. 2): 121-132. (Bi, E, Ee)

Augener, H. 1922. Ueber litorale Polychaeten von Westindien. Sitz. Ges. Naturf. Fruende Berlín 1922(3- 5): 38-53. (B, P)

Ballance, L.T., R.L. Pitman \& P.C. Fiedler. 2006. Oceanographic influences on seabirds and cetaceans of the eastern tropical Pacific: A review. Prog. Oceanog. 69: 360-390. A, E, Mm, Of

Bandy, O.L. \& R.E. Arnal. 1957. Distribution of Recent Foraminifera off the west coast of Central America. Bull. Amer. Assoc. Petrol. Geol. 41: 2037-2053. $(\mathrm{B}, \mathrm{F})$

Barnard, J.L. 1954. Amphipoda of the family Ampelisceidae collected in the eastern Pacific by the Velero III and Velero IV. Allan Hancock Pac. Exped. 18: 1-137. $(\mathrm{B}, \mathrm{Ca})$

Barnard, J.L. \& C.M. Barnard. 1982. Revision of Foxiphalus and Eobrolgus (Crustacea: Amphipoda: Phoxocephalidae) from American Oceans. Smithsonian Contr. Zool. 372: 1-35. (B, Ca)

Bednarski, M. \& A. Morales-Ramírez. 2004. Composition, abundance and distribution of macrozooplankton in Culebra Bay, Gulf of Papagayo, Pacific coast of Costa Rica and its value as bioindicator of pollution. Rev. Biol. Trop. 52 (Suppl. 2): 105-118. (B, E, Plz)

Beebe, W. 1938. Eastern Pacific expeditions of the New York Zoological Society, XIV. Introduction, itinerary, list of stations, nets and dredges of the eastern Pacific Zaca expedition, 1937-1938. Zoologica 23: 287-298. (Ep)

Beebe, W. 1942. Eastern Pacific expeditions of the New York Zoological Society, XXX. Atlantic and Pacific fishes of the genus Dixonina. Zoologica 27: 43-48. (B, Pi)

Berry, S.S. 1958. Notices of new eastern Pacific Mollusca II. Leaflets in Malacology 1: 83-90. (B, Mg)

Bezy, M.B., C. Jiménez, J. Cortés, A. Segura, A. León, J. J. Alvarado, C. Gillén \& E. Mejía. 2006. Contrasting Psammocora-dominated coral communities in Costa Rica, tropical eastern Pacific. Proc. 10th Int. Coral Reef Symp., Okinawa: 376-381. (E, Ar)
Bolaños, R., A. Flores, R.T. Taylor \& L. Cerdas. 1974. Color patterns and venom characteristics in Pelamis platurus. Copeia 1974: 909-912. (E, Q, R)

Breedy, O. 2009. Octocorals. Texto: Pp. 161-167, Lista de especies: Disco Compacto Pp. 108-111. In: I.S. Wehrtmann and J. Cortés (Eds.). Marine Biodiversity of Costa Rica, Central America. Springer, Berlín. (B, $\mathrm{CnA})$

Breedy, O. \& H.M. Guzman. 2003. Octocorals from Costa Rica: The genus Pacifigorgia (Coelenterata: Octocorallia: Gorgoniidae). Zootaxa 281: 1-60. (B, CnA)

Breedy, O. \& H.M. Guzman. 2005. A new species of Leptogorgia (Coelenterata: Octocorallia: Gorgoniidae) from the shallow waters of the eastern Pacific. Zootaxa 899: 1-11. (B, CnA)

Breedy, O. \& H.M. Guzman. 2007. A revision of the genus Leptogorgia Milne Edwards \& Haime, 1857 (Coelenterata: Octocorallia: Gorgoniidae) in the eastern Pacific. Zootaxa 1407: 1-90. (B, CnA)

Breedy, O. \& H.M. Guzman. 2011. A revision of the genus Heterogorgia Verrill, 1868 (Coelenterata: Octocorallia: Plexauridae. Zootaxa 2995: 27-44. (B, CnA)

Brusca, R.C. \& E.W. Iverson. 1985. A guide to the marine isopod Crustacea of Pacific Costa Rica. Rev. Biol. Trop. 33 (Suppl. 1): 1-77. (B, Ci)

Bussing, W.A. \& M. López. 2009. Marine fish. Texto: Pp. 453-458, Lista de especies: Disco Compacto Pp. 412-473. In: I.S. Wehrtmann and J. Cortés (Eds.). Marine Biodiversity of Costa Rica, Central America. Springer, Berlín. (B, Pi)

Cabrera-Peña, J. \& Y. Solano-López. 1996. Tamaños y frecuencia de Pontonia margarita (Crustacea: Palaemonidae) asociada a Pinctada mazatlanica (Bivalvia: Pteriidae), Costa Rica. Rev. Biol. Trop. 44: 915-917. (E, Cd, Mb)

Cabrera-Peña, J., F. Vives-Jiménez \& Y. Solano-López. 1994. Tamaños y relación sexual de Ucides occidentalis (Crustacea: Gecarcinidae) en el manglar de Estero Panamá, Bahía Culebra. Uniciencia 11: 97-99. (E, Cd, Ma)

Cajiao, M.V. 2012. Aspectos legales del Polo Turístico Golfo de Papagayo, Guanacaste, Costa Rica: régimen especial. Rev. Biol. Trop. 60 (Supl. 2): 225-230. (Lg)

Castellanos, I.A., A. Morales-Ramírez \& E. Suárez-Morales. 2009. Appendicularians (Urochordata). Texto: Pp. 445-452, Lista de especies: Disco Compacto Pp. 411. In: I.S. Wehrtmann and J. Cortés (Eds.). Marine 
Biodiversity of Costa Rica, Central America. Springer, Berlín. (B, U)

Castro, P. 1996. Eastern Pacific species of Trapezia (Crustacea, Brachyura: Trapeziidae), sibling species symbiotic with reef corals. Bull. Mar. Sci. 58: 531-554. (E, Cd)

Cernohorsky, W.O. 1976. The Mitridae of the world, Part I: The Subfamily Mitrinae. Indo-Pac. Mollusca 3(17): 273-528. (B, Mg)

Child, C.A. 1979. Shallow-water Pycnogonida of the Isthmus of Panama and the coast of Middle America. Smithsonian Contr. Zool. 293: 1-86. (B, Pc)

Clark, H.L. 1940. Eastern Pacific expeditions of the New York Zoological Society. XXI. Notes on Echinoderms from the West Coast of Central America. Zoologica 25: 331-352. (B, Ea, Eo)

Clark, H.L. 1948. A report on the Echini of the warmer eastern Pacific based on the collections of the Velero III. Allan Hancock Pac Exped. 8: 225-352. (B, Ee)

Clarke, A.J. 1988. Inertial wind path and sea surface temperature patterns near the Gulf of Tehuantepec and Gulf of Papagayo. J. Geophys. Res. 93: 15491-15501. (Af, $\mathrm{Ct}$ )

Cortés, J. 2001. Requiem for an eastern Pacific seagrass bed, Bahía Culebra, Costa Rica. Rev. Biol. Trop. 49 (Suppl 2): 273-278. (E, S)

Cortés, J. 2012. Historia de la investigación marina en Bahía Culebra, Guanacaste, Costa Rica. Rev. Biol. Trop. 60 (Supl. 2): 19-37. (H)

Cortés, J. \& H.M. Guzmán. 1998. Organismos de los arrecifes coralinos de Costa Rica: Descripción, distribución geográfica e historia natural de los corales zooxantelados (Anthozoa: Scleractinia) del Pacífico. Rev. Biol. Trop. 46: 55-92. (B, CnA)

Cortés, J. \& C.E. Jiménez. 2003. Corals and coral reefs of the Pacific of Costa Rica: history, research and status: 361-385. In: J. Cortés (Ed.). Latin American Coral Reefs. Elsevier, Amsterdam. (E, Ar, H)

Cortés, J. \& M.M. Murillo. 1985. Comunidades coralinas y arrecifes del Pacífico de Costa Rica. Rev. Biol. Trop. 33: 197-202. (E, Ar)

Cortés, J., C.E. Jiménez, A.C. Fonseca \& J.J. Alvarado. 2010. Status and conservation of coral reefs in Costa Rica. Rev. Biol. Trop. 58 (Suppl. 1): 33-50. (E, Ar)

Cortés, J., R. Vargas-Castillo \& J. Nivia-Ruiz. 2012. Marine biodiversity of Bahía Culebra, Guanacaste, Costa
Rica: published records. Rev. Biol. Trop. 60 (Suppl. 2): 39-71. (B)

Crane, J. 1941. Eastern Pacific Expeditions of the New York Zoological Society. XXVI. Crabs of the Genus Uca from the west coast of Central America. Zoologica 26: 145-208. (B, Cd)

Crane, J. 1941. Eastern Pacific Expeditions of the New York Zoological Society. XXIX. On the growth and ecology of Brachyuran crabs of the Genus Ocypode. Zoologica 26: 297-310.(E, Cd)

Crane, J. 1947. Eastern Pacific Expeditions of the New York Zoological Society. XXXVIII. Intertidal brachygnathous crabs from the west coast of tropical America with special reference to ecology. Zoologica 32: 69-95. (B, Cd)

Crouch, R.W. \& C.W. Poag. 1987. Benthic Foraminifera of the Panamanian Province: distribution and origins. J. Foram. Res. 17: 153-176. (B, F)

Cushman, J.A. \& I. McCulloch. 1939. A report on some arenaceous Foraminifera. Allan Hancock Pac. Exped. 6: 1-113. (B, F)

Cushman, J.A. \& I. McCulloch. 1940. Some Nonionidae in the Collections of the Allan Hancock Foundation. Allan Hancock Pac. Exped. 6: 145-178. (B, F)

Cushman, J.A. \& I. McCulloch. 1942. Some Virgulininae in the Collections of the Allan Hancock Foundation. Allan Hancock Pac. Exped. 6: 179-230. (B, F)

Cushman, J.A. \& I. McCulloch. 1948. The species of Bulimina and related genera in the collections of the Allan Hancock Foundation. Allan Hancock Pac. Exped. 6: 231-294. (B, F)

Dawson, E.Y. 1957. Marine algae from the Pacific Costa Rican gulfs. Los Angeles County Mus. Contr. Sci. 15: 1-28. (B, Al)

Dawson, E.Y. 1960. New records of marine algae from Pacific Mexico and Central America. Pac. Nat. 1(20): 31-52. (B, Al)

Dawson, E.Y. 1961. A guide to the literature and distributions of Pacific benthic algae from Alaska to the Galapagos Islands. Pac. Sci. 15: 370-461. (B, Al)

Dawson, E.Y. \& P.T. Beaudette. 1959. Field notes from the 1959 eastern Pacific cruise of the Stella Polaris. Pac. Nat. 1 (13): 1-24. (Ep)

Dean, H.K. 2004. Marine biodiversity of Costa Rica: Class Polychaeta (Annelida). Rev. Biol. Trop. 52 (Suppl. 2): 131-181. (B, P) 
Deichmann, E. 1958. The Holothurioidea collected by the Velero III and IV during the years 1932 to 1954. Part II. Aspidochirota. Allan Hancock Pac. Exped. 11: 253-349. (B, Eh)

Denyer, P. \& O. Arias. 1993. Geología del norte de la Península de Nicoya, Costa Rica. Rev. Geól. Amér. Central, 16: 69-84. (G)

Dominici-Arosemena, A., E. Brugnoli-Olivera, J. CortésNúñez, H. Molina-Ureña \& M. Quesada-Alpízar. 2005. Community structure of eastern Pacific reef fishes (Gulf of Papagayo, Costa Rica). Tecnociencia 7(2): 19-41. (E, Pi)

Drouet, F. 1936. Myxophyceae of the G. Allan Hancock Expedition of 1934, collected by Wm. R. Taylor. Allan Hancock Pac. Exp. 3: 15-32. (B, Al)

Durham, J.W. \& J.L. Barnard. 1952. Stony corals of the Eastern Pacific collected by the Velero III and the Velero IV. Allan Hancock Pac. Exped. 16: 1-110. $(\mathrm{B}, \mathrm{CnA})$

Fernández, C. \& J.J. Alvarado. 2008. Chlorophyta de la costa Pacífica de Costa Rica. Rev. Biol. Trop. 56 (Suppl. 4): 149-162. (B, Al)

Fernández, C. \& J. Cortés. 2005. Reef Site: Caulerpa sertularioides, a green alga spreading aggressively over coral reef communities in Culebra Bay, North Pacific of Costa Rica. Coral Reefs 24: 10. (E, Al)

Fernández-García, C., J. Cortés, J.J. Alvarado \& J. NiviaRuiz. 2012. Physical factors contributing to the benthic dominance of the alga Caulerpa sertularioides (Caulerpaceae, Chlorophyta) in the upwelling Bahía Culebra, north Pacific of Costa Rica. Rev. Biol. Trop., 60 (Suppl. 2): 93-107. (Al, E)

Fiedler, P.C. 2002. The annual cycle and biological effects of the Costa Rica Dome. Deep-Sea Res. I 49: 321338. $(\mathrm{Ct})$

Fradin, E. 1892. Estudios del Golfo de Nicoya, de la Bahía de Cocos y del Golfo de Culebra. Tipografía Nacional, San José: 97-106. (Re-impreso en Carlos Meléndez Ch. 1974. Viajes por Guanacaste. NOS VEN 4: 273-290). (G, H)

Fraser, C.M. 1938. Hydroids of the 1934 Hancock Pacific Expeditions. Allan Hancock Pac. Exped. 4: 1-105. $(\mathrm{B}, \mathrm{CnH})$

Fraser, C.M. 1943. General account of the scientific work of the Velero III in the eastern Pacific, 1931-41, Part I, Historical introduction, Velero III, personnel. Allan Hancock Pac. Exped. 1: 1- 48. (Ep)
Fraser, C.M. 1943. General account of the scientific work of the Velero III in the eastern Pacific, 1931-1941, Part II: Geographic and biological associations. Allan Hancock Pac. Exped. 1: 49-258. (Ep)

Fraser, C.M. 1943. General account of the scientific work of the Velero III in the eastern Pacific, 1931-1941, Part III: a ten-year list of the Velero III collecting stations (Charts 1-115). With an appendix of collecting stations of the Allan Hancock Foundation for the year 1942. Allan Hancock Pac. Exped. 1: 259-431. (Ep)

Fraser, C.M. 1948. Hydroids of the Allan Hancock Pacific Expeditions since March, 1938. Allan Hancock Pac. Exped. 4: 179-335. (B, CnH)

Fritzsche, R.A. 1980. Revision of the Eastern Pacific Syngnathidae (Pisces: Sisyngnathiformes), including both Recent and fossil forms. Proc. California Acad. Sci. 42: 181-227. (B, Pi)

García, V., J. Acuña-González, J.A. Vargas-Zamora \& J. García-Céspedes. 2006. Calidad bacteriológica y desechos sólidos en cinco ambientes costeros de Costa Rica. Rev. Biol. Trop. 54 (Supl. 1): 35-48. $(\mathrm{Q}, \mathrm{Cb})$

García-Céspedes, J., J.A. Acuña-González \& J.A. VargasZamora. 2004. Metales traza en sedimentos de cuatro ambientes costeros de Costa Rica. Rev. Biol. Trop. 52 (Supl. 2): 51-60. (Q, Cm)

Garth, J.S. 1940. Some new species of Brachyuran crabs from Mexico and the Central and South American mainland. Allan Hancock Pac. Exped. 5: 53-127. $(\mathrm{B}, \mathrm{Cd})$

Garth, J.S. 1958. Brachyura of the Pacific coast of America. Oxyrhyncha. Tables and Plates. Allan Hancock Pac. Exped. 21: 501-854. (B, Cd)

Garth, J.S. 1959. Eastern Pacific Expeditions of the New York Zoological Society. XLIV. Non-intertidial brachygnathous crabs from the west coast of Tropical America. Part 1: Brachygnatha, Oxyrhyncha. Zoologica 44: 105-126. (B, Cd)

Garth, J.S. 1961. Eastern Pacific Expeditions of the New York Zoological Society. XLV. Non-intertidial brachygnathous crabs from the west coast of Tropical America. Part 2: Brachygnatha Brachyrhyncha. Zoologica 46: 133-160. (B, Cd)

Garth, J.S. 1966. Eastern Pacific Expeditions of the New York Zoological Society. XLVI. Oxystomatous and allied crabs from the west coast of Tropical America. Zoologica 51: 1-16. (B, Cd) 
Gateño, D., A. León, Y. Barki, J. Cortés \& B. Rinkevich. 2003. Skeletal tumor formations in the massive coral Pavona clavus. Mar. Ecol. Prog. Ser. 258: 97-108. (CoE)

Glynn, P.W., E.M. Druffel \& R.B. Dunbar. 1983. A dead Central American coral reef tract: possible link with the Little Ice Age. J. Mar. Res. 41: 605-637. (E, Ar)

Gore, R. 1982. Porcellanid crabs from the coasts of Mexico and Central America (Crustacea: Decapoda: Anomura). Smithsonian Contr. Zool. 363: 1-34. (B, Cd)

Grau, G. 1959. Pectinidae of the eastern Pacific. Allan Hancock Pac. Exped. 23: 1-308. (B, Mb)

Gravel, P., K. Johanning, J. McLachlan, J. A. Vargas \& E. Oberdörster. 2006. Imposex in the intertidal snail Thais brevidentata (Gastropoda: Muricidae) from the Pacific coast of Costa Rica. Rev. Biol. Trop. 54 (Suppl. 1): 21-26. (De, Mg)

Haig, J. 1960. The Porcellanidae (Crustacea: Anomura) of the eastern Pacific. Allan Hancock Pac. Exped. 241440. (B, Cd)

Haig, J. 1968. Eastern Pacific expeditions of the New York Zoological Society. Porcellanid crabs (Crustacea: Anomura) from the west coast of Tropical America. Zoologica 53: 57-74. (B, Cd)

Hanna, G.D. \& A.M. Strong. 1949. West American mollusks of the genus Conus. Proc. Cal. Acad. Sci. 4th ser., XXVI: 247-322. (B, Mg)

Hartman, O. 1940. Polychaetous Annelids. Part II. Chrysopetalidae to Goniadidae. Allan Hancock Pac. Exped. 7: 173-287. (B, P)

Hartman, O. 1944. Polychaetous annelids. Pt. V. Eunicea. Allan Hancock Pac. Exped. 10: 1-238. (B, P)

Hartman, O. 1944. Polychaetous annelids. Pt. VI. Paraonidae, Magelonidae, Longosomidae, Ctenodrilidae and Sabellariidae. Allan Hancock Pac. Exped. 10: 311-389. (B, P)

Hendrickx, M.E. \& M.K. Wicksten. 1989. Los Pandalidae (Crustacea: Caridea) del Pacífico mexicano, con una clave para su identificación. Caldasia 16: 71-86. $(\mathrm{B}, \mathrm{Cd})$

Henry, D.P. \& P.A. McLaughlin. 1967. A revision of the subgenus Solidabalanus Hoek (Cirripedia, Thoracica) including a description of a new species with complemental males. Crustaceana 12: 43-58. (B, Cc)
Henry, D.P. \& P.A. McLaughlin. 1975. The barnacles of the Balanus amphitrite complex (Cirripedia, Thoracica). Zool. Verh. 141: 1-254. (B, Cc)

Herrera-Zúñiga, P. \& A.E. Vargas. 2012. Geología de Bahía Culebra, Guanacaste, Costa Rica. Rev. Biol. Trop. 60 (Supl. 2): 213-223. (Ge)

Hertlein, L.G. \& A.M. Strong. 1943. Eastern Pacific Expeditions of the New York Zoological Society. XXXII. Mollusks from the West Coast of Mexico and Central America. Part II. Zoologica 28: 149-168. (B, Mb)

Hertlein, L.G. \& A.M. Strong. 1946. Eastern Pacific Expeditions of the New York Zoological Society. XXXIV. Mollusks from the West Coast of Mexico and Central America. Part III. Zoologica 31: 53-76. (B, Mb)

Hertlein, L.G. \& A.M. Strong. 1946. Eastern Pacific Expeditions of the New York Zoological Society. XXXV. Mollusks from the West Coast of Mexico and Central America. Part IV. Zoologica, 31: 93-120. (B, Mb)

Hertlein, L.G. \& A.M. Strong. 1947. Eastern Pacific Expeditions of the New York Zoological Society. XXXVI. Mollusks from the West Coast of Mexico and Central America. Part V. Zoologica 31: 129-150. (B, Mb)

Hertlein, L.G. \& A.M. Strong. 1948. Eastern Pacific Expeditions of the New York Zoological Society. XXXIX. Mollusks from the West Coast of Mexico and Central America. Part VI. Zoologica 33: 163-198. (B, Mb)

Hertlein, L.G. \& A.M. Strong. 1949. Eastern Pacific Expeditions of the New York Zoological Society. XL. Mollusks from the West Coast of Mexico and Central America. Part VII. Zoologica 34: 63-97. (B, Mb)

Hertlein, L.G. \& A.M. Strong. 1949. Eastern Pacific Expeditions of the New York Zoological Society. XLI. Mollusks from the West Coast of Mexico and Central America. Part VIII. Zoologica 34: 239-258. (B, Mb)

Hertlein, L.G. \& A.M. Strong. 1950. Eastern Pacific Expeditions of the New York Zoological Society. XLII. Mollusks from the West Coast of Mexico and Central America. Part IX. Zoologica 35: 217-252. (B, Mb)

Hertlein, L.G. \& A.M. Strong. 1951. Eastern Pacific Expeditions of the New York Zoological Society. XLIII. Mollusks from the West Coast of Mexico and Central America. Part X. Zoologica 36: 66-120. (B, Mb)

Hertz, C.M., B.W. Myers \& J. Gemmell. 1992. Two new vitrinellid species from the Gulf of California, Mexico (Gastropoda: Vitrinellidae). Veliger 35: 70-73. (B, Mg) 
Hoberg, E.P., D.R. Brooks, H. Molina-Ureña \& E. Erbe. 1998. Echinocephalus janzeni n.sp. (Nematoda: Gnathostomatidae) in Himantura pacifica (Chondrichthyes: Myliobatiformes) from the Pacific coast of Costa Rica and Mexico, with historial biogeographic analysis of the genus. J. Parasitol. 84: 571-581. (B, $\mathrm{N}, \mathrm{Pi}, \mathrm{Pp}$ )

Jiménez, C.E. 1997. Corals and coral reefs of Culebra Bay, Pacific coast of Costa Rica: Anarchy in the reef. Proc. 8th Int. Coral Reef Symp., Panamá 1: 329-334. (E, Ar)

Jiménez, C. 2001. Seawater temperature measured at the surface and at two depths (7 and $12 \mathrm{~m}$ ) in one coral reef at Culebra Bay, Gulf of Papagayo, Costa Rica. Rev. Biol. Trop. 49 (Suppl. 2): 153-161. (Ar, Of)

Jiménez, C. 2001. Arrecifes y ambientes coralinos de bahía Culebra, Pacífico de Costa Rica: aspectos biológicos, económico-recreativos y de manejo. Rev. Biol. Trop. 49 (Supl. 2): 215-231. (Ar, Se, M)

Jiménez, C.E. \& J. Cortés. 2003. Growth of seven species of scleractinian corals in an upwelling environment of the eastern Pacific (Golfo de Papagayo, Costa Rica). Bull. Mar. Sci. 72: 187-198. (E, CnA)

Jiménez, C., J. Cortés, A. León \& E. Ruiz. 2001. Coral bleaching and mortality associated with El Niño $1997 / 98$ event in an upwelling environment in the eastern Pacific (Gulf of Papagayo, Costa Rica). Bull. Mar. Sci. 69: 151-169. (E, Ar, EN)

Jiménez, C., G. Bassey, Á. Segura \& J. Cortés. 2010. Characterization of the coral communities and reefs of two previously undescribed locations in the upwelling region of Gulf of Papagayo (Costa Rica). Rev. Cienc. Mar. Cost. 2: 95-108. (E, Ar)

Jung, P. 1989. Revision of the Strombina-Group (Gastropoda: Columbellidae), Fossil and Living: Distribution, Biostratigraphy and Systematics. Schweiz. Paläont. Abhandl. 111: 1-298. (B, Mg)

Karnauskas, K.B., A.J. Busalacchi \& R. Murtugudde. 2008. Low-frequency variability and remote forcing of gap winds over the East Pacific Warm Pool. J. Clim. 21: 4901-4918. (Af, Ct)

Kelmo, F. \& R. Vargas. 2002. Anthoathecatae and Leptothecatae hydroids from Costa Rica (Cnidaria: Hydrozoa). Rev. Biol. Trop. 50: 599-627. (B, CnH)

Kim, W. \& L.G. Abele. 1988. The snapping shrimp genus Alpheus from the eastern Pacific (Decapoda: Caridea: Alpheidae). Smithsonian Contr. Zool. 454: 1-119. (B, Cd)
Lalicker, C.G. \& I. McCulloch. 1940. Some Textulariidae of the Pacific Ocean. Allan Hancock Pac. Exped. 6: 115-143. (B, F)

Lizano, O. 2006. Algunas características de las mareas en la costa Pacífica y Caribe de Centroamérica. Cienc. Tecn. 24: 51-64. (Of)

Lizano, O.G., L.G. Loría, E.J. Alfaro \& M. Badilla. 2008. Distribución espacial de radionucleídos en sedimentos marinos de Bahía Culebra y el Golfo de Nicoya, Pacífico, Costa Rica. Rev. Biol. Trop. 56 (Supl. 4): 83-90. (Cr)

Lizano, O.G., E.J. Alfaro \& A. Salazar-M. 2012. Elaboración de una herramienta para la evaluar enriquecimiento de metales en sedimentos marinos de Bahía Culebra y el Golfo de Nicoya, Pacífico, Costa Rica. Rev. Biol. Trop. 60 (Supl. 2): 197-211. (Cr)

Madrigal-Castro, E., J. Cabrera-Peña, J. Monge-Esquivel \& F. Pérez-Acuña. 1984. Comparación entre dos poblaciones de Acanthina brevidentata (Gastropoda: Mollusca) en dos zonas rocosas de Playa Panamá, Guanacaste, Costa Rica. Rev. Biol. Trop. 32: 11-15. (E, $\mathrm{Mg}, \mathrm{Zr}$ )

Manning, R.B. 1971. Eastern Pacific Expeditions of the New York Zoological Society. Stomatopod Crustacea. Zoologica 56: 95-113. (B, Cs)

Manning, R.B. 1974. Stomatopods collected by Th. Mortensen in the eastern Pacific Region (Crustacea, Stomatopoda). Steenstrupia 3(11): 101-109. (B, Cs)

Manter, H.W. 1940. Digenetic trematodes of fishes from the Galapagos Islands and the neighboring Pacific. Allan Hancock Pac. Exped. 2: 329-497. (B, Pp, Pt)

Marques, F., D.R. Brooks \& H. Molina-Ureña. 1996. Two new species of Tetraphyllidean Cestodes in Himantura pacifica (Chondrichthyes: Myliobatiformes: Dasyatididae) from the northwest Coast of Costa Rica. J. Parasitol. 82: 302-306. (B, Pp, Pt)

May-Collado, L. 2009. Marine mammals. Texto: Pp. 479495, Lista de especies: Disco Compacto Pp. 485-490. In: I.S. Wehrtmann and J. Cortés (Eds.). Marine Biodiversity of Costa Rica, Central America. Springer, Berlín. (B, Mm)

May-Collado, L.J. \& J. Forcada. 2012. Small scale abundance of coastal spotted dolphins (Stenella attenuata graffmani): the effect of habitat and seasonality. Rev. Biol. Trop. 60 (Suppl. 2): 133-142. (E, Mm)

May-Collado, L. \& A. Morales-Ramírez. 2005. Presencia y patrones de comportamiento del delfín manchado costero, Stenella attenuata (Cetacea: Delphinidae) en 
el Golfo de Papagayo, Costa Rica. Rev. Biol. Trop. 53: 265-276. (E, Mm)

May-Collado, L., T. Gerrodette, J. Calambokidis, K. Rasmussen \& I. Sereg. 2005. Patterns of cetacean sighting distribution in the Pacific Exclusive Economic Zone of Costa Rica based on data collected from 1979-2001. Rev. Biol. Trop. 53: 249-263. (E, Mm)

McCreary, J.P., H.S. Lee \& D.B. Enfield. 1989. The response of the coastal ocean to strong offshore winds: with application to circulations in the Gulfs of Tehuantepec and Papagayo. J. Mar. Res. 47: 81-109. (Af, $\mathrm{Ct}$ )

McLaughlin, P.A. 1981. Revision of Pylopagurus and Tomopagurus (Crustacea: Decapoda: Paguridae), with the descriptions of new genera and species: Part II. Rhodochirus McLaughlin and Phimochirus McLaughlin. Bull. Mar. Sci. 31: 329-365. (B, Cd)

McLean, J.H. \& R. Poorman. 1971. New species of tropical eastern Pacific Turridae. Veliger 14: 89-113. (B, Mg)

Meserve, F.G. 1938. Some monogenetic trematodes from the Galapagos Islands and the neighboring Pacific. Allan Hancock Pac. Exped. 2: 31-89. (B, Pp, Pt)

Miller, A.C. 1983. A comparison of the species richness and roles of gastropods and chitons on rocky shores of temperate and tropical West America. Veliger 26: 62-68. E, Mg, Mc,Zr

Monks, S., F. Marques, V. León-Régagnon \& G. PérezPonce de León. 1997. Koronacantha pectinaria n. comb. (Acanthocephala: Illiosentidae) from Microlepidotus brevipinnis (Haemulidae) and redescription of Tegorhynchus brevis. J. Parasitol. 83: 485-494. Ac, B, Pp

Morales-Ramírez, A., R. Víquez, K. Rodríguez y M. Vargas. 2001. Marea roja producida por Lingulodinium polyedrum (Peridiniales, Dinophyceae) en Bahía Culebra, Golfo de Papagayo, Costa Rica. Rev. Biol. Trop. 49 (Supl. 2): 19-23. (E, Mr, Plf)

Muller-Parker, G. \& J. Cortés. 2001. Spatial distribution of light and nutrients in some coral reefs of Costa Rica during January 1997. Rev. Biol. Trop. 49 (Suppl. 2): 251-263. (E, Ar, Of, Q)

Osburn, R.C. 1950. Bryozoa of the Pacific Coast of America. Part I, Cheilostomata-Anasca. Allan Hancock Pac. Exped. 14: 1-269. (B, Br)

Osburn, R.C. 1952. Bryozoa of the Pacific Coast of America. Part 2, Cheilostomata-Ascophora. Allan Hancock Pac. Exped. 14: 271-611. (B, Br)
Osburn, R.C. \& J.D. Soule. 1953. Bryozoa of the Pacific Coast of America. Part 3, Order Ectoprocta. Allan Hancock Pac. Exped. 14: 726-758. (B, Br)

Pérez-Ponce de León, G., V. León-Regagnon \& S. Monks. 1998. Theletrum lamothei sp. nov. (Digenea), parasite of Echidna nocturna from Cuajiniquil, Guanacaste, and other digenes of marine fishes from Costa Rica. Rev. Biol. Trop. 46: 345-354. (B, Pp, Pt)

Pfeiler, E. 2008. Resurrection of the name Albula pacifica (Beebe, 1942) for the shafted bonefish (Albuniformes: Albulidae) from the eastern Pacific. Rev. Biol. Trop. 56: 839-844. (B, Pi)

Rathbun, M.J. 1937. The Oxystomatous and allied crabs of America. U.S. Natl. Mus. Bull. 166: 1-272. (B, Cd)

Reid, D.G. 2002. The genus Nodilittorina von Martens, 1897 (Gastropoda: Littorinidae) in the eastern Pacific Ocean, with a discussion of Biogeographic Provinces of the rocky-shore fauna. Veliger 45: 85-170. (B, $\mathrm{Mg}, \mathrm{Zr}$ )

Ríos, R. 1986. Caridean shrimps of the Gulf of California. V. New records of species belonging to the subfamily Pontoniinae (Crustacea: Decapoda: Palaemonidae). Proc. Biol. Soc. Wash. 99: 429-434. (B, Cd)

Rodríguez-Ortíz, B., L. García-Prieto \& G. Pérez-Ponce de León. 2004. Checklist of the helminth parasites of vertebrates in Costa Rica. Rev. Biol. Trop. 52: 313354. (B, Ac, Pp, Pt)

Rodríguez-Sáenz, K. \& R. Gasca. 2009. Siphonophores. Texto: Pp. 151-156, Lista de especies, CD: Pp. 101104. In: I.S. Wehrtmann \& J. Cortés (Eds.). Marine Biodiversity of Costa Rica, Central America. Springer, Berlín. (B, CnH)

Rodríguez-Sáenz, K. \& J. Rodríguez-Fonseca. 2004. Avistamientos del delfín manchado, Stenella attenuata (Cetacea: Delphinidae) en Bahía Culebra, Costa Rica, 1999-2000. Rev. Biol. Trop. 52 (Supl. 2): 189-193. (E, Mm)

Rodríguez-Sáenz, K. \& L. Segura-Puertas. 2009. Hydrozoa, Scyphozoa, and Cubozoa (Medusozoa). Texto: Pp. 143-149, Lista de especies, CD: Pp. 94-100. In: I.S. Wehrtmann \& J. Cortés (Eds.). Marine Biodiversity of Costa Rica, Central America. Springer, Berlín. (B, $\mathrm{CnH}, \mathrm{CnM})$

Romero-Centeno, R., J. Zavala-Hidalgo \& G.B. Raga. 2007. Midsummer gap winds and low-level circulation over the Eastern Tropical Pacific. J. Climt. 20: 3768-3784. (Ct) 
Rost, H. 1955. A report on the Family Arcidae (Pelecypoda). Allan Hancock Pac. Exped. 20: 177-249. (B, Mb)

Samper-Villareal, J., J. Cortés \& C. Benavides. 2012. Forest structure and area of mangrove stands at Bahía Culebra, northern Pacific coast of Costa Rica. Rev. Biol. Trop. 60 (Suppl. 2): 109-120. (E, Ma)

Sánchez-Noguera, C. 2012. Entre historias y culebras: más que una bahía (Bahía Culebra, Guanacaste, Costa Rica). Rev. Biol. Trop. 60 (Supl. 2): 1-17. (H)

Savage, J.M. 2002. The Amphibians and Reptiles of Costa Rica: A Herpetofauna Between Two Continents, Between Two Seas. Univ. Chicago Press, Chicago, London. 934 p. (B, R)

Schmitt, W.L. 1940. The Stomatopods of the West Coast of America, based on collections made by the Allan Hancock Expeditions, 1933-38. Allan Hancock Pac. Exped. 5: 129-225. (B, CS)

Skoglund, C. 2001. Panamic Province Molluscan Literature. Additions and changes from 1971 through 2000. I. Bivalvia. Festivus 32 (Supplement): 119 p. (B, Mb)

Skoglund, C. 2002. Panamic Province Molluscan Literature. Additions and changes from 1971 through 2001. III Gastropoda. Festivus 33 (Supplement): 286 p. (B, Mg)

Solís-Marín, F.A., J.A. Arriaga-Ochoa, A. LaguardaFigueras, S.C. Frontana-Uribe \& A. Durán-González. 2009. Holoturoideos (Echinodermata: Holothuroidea) del Golfo de California. CONABIO, ICMyL, UNAM. México DF. 177 p. (B, Eh)

Soot-Ryen, T. 1955. A report on the Family Mytilidae (Pelecypoda). Allan Hancock Pac. Exped. 20: 1-175. (B, $\mathrm{Mb})$

Spongberg, A.L. 2004. PCB Contamination in surface sediments in the coastal waters of Costa Rica. Rev. Biol. Trop. 52 (Suppl. 2): 1-10. (Cpc)

Spongberg, A.L. 2006. PCB concentrations in intertidal sipunculan (Phylum Sipuncula) marine worms from the Pacific coast of Costa Rica. Rev. Biol. Trop. 54 (Suppl. 1): 27-33. (Cpc, Si)

Suárez-Morales, E. \& A. Morales-Ramírez. 2003. A new species of Cymbasoma (Crustacea: Copepoda: Monstrilloida) from the Pacific coast of Costa Rica, Central America. Proc. Biol. Soc. Washington 116: 206-214. $(\mathrm{B}, \mathrm{Cco})$

Sunagawa, S., J. Cortés, C. Jiménez \& R. Lara. 2008. Variación en la densidad de células y en las concentraciones de pigmentos de los dinoflagelados simbióticos del coral Pavona clavus en el Pacífico Oriental (Costa Rica). Cienc. Mar. 34: 113-123. (Ar, CnA, E, Zx)

Tarrant, A.M., J. Cortés, M. Atkinson, S. Atkinson, K. Johanning, T.-c. Chiang, J.A. Vargas \& J.A. McLachlan. 2008. Three orphan nuclear receptors in the scleractinian coral Pocillopora damicornis from the Pacific coast of Costa Rica. Rev. Biol. Trop. 56 (Suppl. 4): 39-48. (CnA, Nr)

Taylor, E.H. 1953. Early records of the seasnake Pelamis platurus in Latin America. Copeia 1953: 124. (H, R)

Taylor, W.R. 1945. Pacific marine algae of the Allan Hancock Pacific Expeditions to the Galapagos Islands. Allan Hancock Pacific Exped. 12: 1-528. (B, Al)

Tovar-Hernández, M.A. \& L.F. Carrera-Parra. 2011. Megalomma Johansson, 1925 (Polychaeta: Sabellidae) from America and other world-wide localities, and phylogenetic relationships within the genus. Zootaxa 2861: 1-71. (B, P)

Tsuda, R.T. 1968. Additional records of the marine algae from Costa Rica. Carib. J. Sci. 8: 103-104. (B, Al)

Tu, A.T. 1976. Investigation of the sea snake, Pelamis platurus (Reptilia, Serpentes, Hydrophiidae), on the Pacific coast of Costa Rica, Central America. J. Herpetol. 10: 13-18. (E, R)

Türkay, M. 1970. Die Gecarcinidae Amerikas. Mit einem Anhang über Ucides Rathbun. Sencken. Biol. 51: 333-354. (B, Cd)

Valdés, Á. \& Y.E. Camacho-García. 2004. "Cephalaspidean" Heterobranchs (Gastropoda) from the Pacific Coast of Costa Rica. Proc. California Acad. Sci. 55: 459-497. (B, Mg)

Van Cleave, H.J. 1940. The Acanthocephala collected by the Allan Hancock Pacific Expedition, 1934. Allan Hancock Pac. Exped. 2: 501-527. (Pp, Ac)

Vargas-Castillo, R. 2012. Nuevas adiciones a la fauna de crustáceos decápodos de Bahía Culebra, Guanacaste, Costa Rica. Rev. Biol. Trop. 60 (Supl. 2): 73-76. (B, Cd)

Vargas, R. \& J. Cortés. 1997. Biodiversidad marina de Costa Rica: Orden Stomatopoda (Crustacea: Hoplocarida). Rev. Biol. Trop. 45: 1531-1539. (B, Cs)

Vargas, R. \& J. Cortés. 1999. Biodiversidad marina de Costa Rica: Crustacea. Decapoda (Penaeoidea, Sergestoidea, Caridea, Astacidea, Thalassinidea, Palinura) del Pacífico. Rev. Biol. Trop. 47: 887-911. (B, Cd) 
Vargas, R. \& J. Cortés. 2006. Biodiversidad marina de Costa Rica: Crustacea: Infraorden Anomura. Rev. Biol. Trop. 54: 461-488. (B, Cd)

Wehrtmann, I.S. \& R. Vargas. 2003. New records and range extensions of shrimps (Decapoda: Penaeoidea, Caridea) from the Pacific and Caribbean coasts of Costa Rica, Central America. Rev. Biol. Trop. 51: 268-274. (B, Cd)

Wicksten, M.K. 1983. Shallow water caridean shrimps of the Gulf of California, México. Allan Hancock Monogr. Mar. Biol. 13: 1-59. (B, Cd)

Wicksten, M.K. \& M.E. Hendrickx. 1992. An updated checklist of benthic marine and brackish water shrimps (Decapoda: Penaeoidea, Stenopodidea, Caridea) from the Eastern Tropical Pacific: 49-76. In:
M.E. Hendrickx (ed.), Contributions to the Study of East Pacific Crustaceans, 2. [Contribuciones al estudio de los Crustáceos del Pacífico Este, 2]. Instituto de Ciencias del Mar y Limnología, UNAM. (B, Cd)

Wilson, C.B. 1937. Parasitic copepods taken during the third Hancock expedition to the Galapagos Islands. Allan Hancock Pac. Exped. 2: 23-31. (Pp, Cco)

Zamora, H. 1924. Sardinal, Golfo de Culebra y Bahía de Coco. Rev. Costa Rica Año V, Núm. 8: 200-201. (H)

Zamora-Trejos, P. \& J. Cortés. 2009. Los manglares de Costa Rica: Pacífico norte. Rev. Biol. Trop. 57: 473 488. (E, Ma)

Ziesenhenne, F.C. 1940. New ophiurans of the Allan Hancock Pacific Expeditions. Allan Hancock Pac. Exped. 8: 9-59. (B, Eo)

CUADRO 2

Lista de tesis y libros científicas sobre organismos, ambientes y procesos marinos y atmosféricos de Bahía Culebra o donde se menciona la Bahía

TABLE 2

List of thesis and books in which marine organisms, environments and marine and atmospheric processes from Bahía Culebra or in which the Bay are mentioned

Alpermann, T.J. 2001. The fisheries of ornamental fishes in Guanacaste, Costa Rica with special emphasis on the population dynamics of the Cortez Rainbow wrasse, Thalassoma lucasanum (Gill 1863). Tesis de Maestría, ISATEC, Univ. Bremen. Bremen, Alemania. 84 p. $(\mathrm{E}, \mathrm{Pi}, \mathrm{T})$

Alvarado Velas, Maritta. 2002. Geología de Playa Iguanita y alrededores, Guanacaste, Costa Rica. Informe Campaña Geológica. Escuela Centroamericana de Geología, Universidad de Costa Rica, San Pedro. 81 p. + anexos +2 mapas. (G, I)

Arias, O. \& P. Denyer. 1992. Mapa geológico de la hoja Carrillo Norte, Guanacaste, Costa Rica (1:50 000). Instituto Geográfico Nacional, San José, Costa Rica. (G, Mp)

Bednarski, M. 2001. Macrozooplankton of Culebra Bay, Costa Rica, with an emphasis on copepods. Tesis de Maestría, ISATEC, Univ. Bremen. Bremen, Alemania. 155 p. (E, B, Plz, T)

Beebe, W. 1942. Book of Bays. Barcourt, Brace and Company, New York. 302 p. (E, H, L)
Bezy, M.B. 2009. Reproducción sexual y reclutamiento del coral masivo, Pavona clavus, en Bahía Culebra, Golfo de Papagayo, Costa Rica. Tesis de Maestría, Univ. Costa Rica. San Pedro, Costa Rica. 151 p. (E, CnA, T)

Bravo, J. \& L. Rivera. 1998. Mapas de Humedales de Costa Rica e Información Complementaria. SINAC, MINAE-UICN. Escala 1: 200 000. (Ma, Mp, L)

Camacho-Lizano, D. Caracterización geológica del Sitio Bahía y zonas aledañas, Península de Papagayo. Informe Campaña Geológica. Escuela Centroamericana de Geología, Universidad de Costa Rica, San Pedro. 71 p. + anexos +2 mapas. (G, I)

Chaves-Gamboa, J. 2002. Estudio geológico de la zona de playa Cabuyal y El Triunfo, Guanacaste, Costa Rica. Informe Campaña Geológica. Escuela Centroamericana de Geología, Universidad de Costa Rica, San Pedro. 55 p. + apéndice. (G, I)

Chaves-Gamboa, J. 2002. Estudio geológico del hito Papagayo y alrededores, península de Papagayo, Liberia, Guanacaste. Informe Campaña Geológica. Escuela 
Centroamericana de Geología, Universidad de Costa Rica, San Pedro. 59 p. + apéndice. (G, I)

Córdoba-Muñoz, R., J.C. Romero-Araya \& N.J. Windevoxhel-Lora (Compiladores). 1998. Inventario de los humedales de Costa Rica. UICN, MINAE, SINAC, Embajada Real de los Países Bajos, San José, Costa Rica. 380 p. (L, Ma)

Crane, J. 1975. Fiddler Crabs of the World. Ocypodidae: Genus Uca. Princeton Univ. Press, Princeton, New Jersey. 738 p. (B, Cd, L)

Dengo, G. 1962. Estudio geológico de la región de Guanacaste, Costa Rica. Instituto Geográfico Nacional, San José, Costa Rica. 112 p. (G, L)

Dominici-Arosemena, A. 1999. Estructura poblacional de los peces de arrecifes del Golfo de Papagayo, Guanacaste, Costa Rica, con énfasis en las especies de mayor importancia comercial como ornamentales. Tesis de Maestría, Univ. Costa Rica. San Pedro, Costa Rica. 208 p. ( E, Pi, T)

Fernández-García, C. 2007. Propagación del alga Caulerpa sertularioides (Chlorophyta) en Bahía Culebra, Golfo de Papagayo, Pacífico norte de Costa Rica. Tesis de Maestría, Univ. Costa Rica. San Pedro, Costa Rica. 92 p. (E, Al, T)

Gómez-Tristán, M. 2002. Geología integral de Alto Roble y alrededores, Provincia de Guanacaste, Costa Rica. Informe Campaña Geológica. Escuela Centroamericana de Geología, Universidad de Costa Rica, San Pedro. 90 p. + anexos +2 mapas. $(\mathrm{G}, \mathrm{I})$

Ibarra-Gene, E. 2006. El valor de uso del paisaje submarino en el Golfo de Papagayo: comparación de la industria de buceo deportivo con la industria de extracción de peces de acuario. Licenciatura Economía, Univ. Costa Rica. San Pedro, Costa Rica. 155 p. (Se, T)

Jiménez-Centeno, C.E. 1998. Arrecifes y comunidades coralinas de Bahía Culebra, Pacífico Norte de Costa Rica. Tesis de Maestría, Univ. Costa Rica. San Pedro, Costa Rica. 218 p. (E, Ar, T)

May-Collado, L.J. 2001. Ecología y comportamiento del delfín manchado costero, Stenella attenuata graffma$n i$ (CETACEA: DELPHINIDAE) del Pacifico norte de Costa Rica. Tesis de Maestría, Univ. Costa Rica. San Pedro, Costa Rica. 78 p. (E, Mm, T)

Rodríguez-Sáenz, K. 2005. Distribución espacial y temporal de la biomasa, composición y abundancia del zooplancton, con énfasis en hidromedusas de Bahía Culebra durante La Niña 1999 y el 2000. Tesis de Maestría, Univ. Costa Rica. San José, Costa Rica. 156 p. $(\mathrm{E}, \mathrm{B}, \mathrm{Plz}, \mathrm{CnH}, \mathrm{T})$

Sunagawa, S. 2005. Seasonal variation in symbiont densities and skeletal phosphorus concentrations in the eastern Pacific (Costa Rica) coral Pavona clavus. Tesis de Maestría, ISATEC, Univ. Bremen. Bremen, Alemania. 66 p. (CnA, E, Zx, T)

Vargas-Montero, M. 2004. Floraciones algales en Costa Rica y su relación con algunos factores meteorológicos y consideraciones sobre sus efectos socioeconómicos. Tesis de Maestría, GIACT, Univ. Costa Rica. San Pedro, Costa Rica. 90 p. (E, B, Plf, Mr, T)

Vásquez-Fernández, M. 2002. Geología de la Península de Papagayo, Guanacaste, Costa Rica. Informe Campaña Geológica. Escuela Centroamericana de Geología, Universidad de Costa Rica, San Pedro. 80 p. + anexos +2 mapas. $(\mathrm{G}, \mathrm{I})$ 
CUADRO 3

Número de publicaciones de cada tema. Entre paréntesis el código usado para clasificar cada publicación

TABLE 3

Number of publications by topic. In parenthesis the code used to classify each publication

\begin{tabular}{|c|c|c|c|c|c|}
\hline Tema & \# Publ. & Tema & \# Publ. & Tema & \# Publ. \\
\hline Biodiversidad $=\mathrm{B}$ & 111 & Nematoda $=\mathrm{N}$ & 1 & Manglares = Ma & 5 \\
\hline Ecología = E & 43 & Contaminación & 8 & Reptilia $=\mathrm{R}$ & 4 \\
\hline Crustacea & 38 & $\mathrm{PCBs}=\mathrm{Cpc}$ & 2 & Bryozoa $=\mathrm{Br}$ & 3 \\
\hline Decapoda $=\mathrm{Cd}$ & 28 & Petróleo $=\mathrm{Cp}$ & 2 & Zona $\operatorname{rocosa}=\mathrm{Zr}$ & 3 \\
\hline Stomatopoda $=\mathrm{Cs}$ & 4 & Bacterias $=\mathrm{Cb}$ & 1 & Zooplancton $=\mathrm{Plz}$ & 3 \\
\hline Amphipoda = Ca & 2 & Metales $=\mathrm{Cm}$ & 1 & Fitoplancton $=$ Plf & 2 \\
\hline Copepoda $=\mathrm{Cco}$ & 2 & Radionucleidos $=\mathrm{Cr}$ & 2 & Mapas = Mp & 2 \\
\hline Cirripedia $=\mathrm{Cc}$ & 1 & Peces $=\mathrm{Pi}$ & 8 & Marea $\mathrm{Roja}=\mathrm{Mr}$ & 2 \\
\hline Isopoda $=\mathrm{Ci}$ & 1 & Echinodermata & 7 & Socio-económico $=\mathrm{Se}$ & 2 \\
\hline Mollusca & 26 & Echinoidea $=\mathrm{Ee}$ & 2 & Zooxantelas $=\mathrm{Zx}$ & 2 \\
\hline Bivalvia $=\mathrm{Mb}$ & 13 & Holothuroidea $=\mathrm{Eh}$ & 2 & Aves $=\mathrm{A}$ & 1 \\
\hline Gastropoda $=\mathrm{Mg}$ & 13 & Ophiuroidea $=$ Eo & 2 & Bioerosión = Bi & 1 \\
\hline Polyplacophora $=\mathrm{Mc}$ & 1 & Asteroidea $=\mathrm{Ea}$ & 1 & Corales, enfermedades $=\mathrm{CoE}$ & 1 \\
\hline Cnidaria & 21 & Ciencias atmosféricas $=\mathrm{Ct}$ & 7 & Disruptores endocrinos $=\mathrm{De}$ & 1 \\
\hline Anthozoa $=\mathrm{CnA}$ & 14 & Historia $=\mathrm{H}$ & 7 & El Niño = EN & 1 \\
\hline Hydrozoa $=\mathrm{CnH}$ & 6 & Mamíferos marinos $=\mathrm{Mm}$ & 7 & Geografía $=\mathrm{G}$ & 1 \\
\hline Medusozoa $=\mathrm{CM}$ & 1 & Oceanografía Física = Of & 7 & Legal $=\mathrm{Lg}$ & 1 \\
\hline Arrecifes $=\mathrm{Ar}$ & 13 & Foraminifera $=\mathrm{F}$ & 6 & Manejo $=\mathrm{M}$ & 1 \\
\hline Tesis $=\mathrm{T}$ & 11 & Informes $=\mathrm{I}$ & 6 & Receptores nucleares $=\mathrm{Nr}$ & 1 \\
\hline Algas $=\mathrm{Al}$ & 10 & Polychaeta $=\mathrm{P}$ & 6 & Pastos marinos $=\mathrm{S}$ & 1 \\
\hline Geología $=\mathrm{Ge}$ & 10 & Química = Q & 6 & Picnogónido $=\mathrm{Pc}$ & 1 \\
\hline Parásitos peces $=\mathrm{Pp}$ & 9 & Afloramiento $=\mathrm{Af}$ & 5 & Sipunculida $=\mathrm{Si}$ & 1 \\
\hline Plathyhelminthes $=\mathrm{Pt}$ & 5 & Expediciones $=\mathrm{Ep}$ & 5 & Urochordata $=\mathrm{U}$ & 1 \\
\hline Acantocephala $=\mathrm{Ac}$ & 3 & Libros $=\mathrm{L}$ & 5 & & \\
\hline
\end{tabular}

